\title{
Struggle Against Ignorance by Education the Humanitarian Policy of Uzbekistan
}

Junaydullaev Mels Asliddin o'gli

Master's Student in “Theory and Methods of Education (Ore-service Military Education)” in

Tashkent State Pedagogical University named after Nizami, Uzbekistan.

Copyright: ( 2021 Junaydullaev Mels Asliddin o'gli. This is an open access article distributed under the terms of the Creative Commons Attribution License, which permits unrestricted use, distribution, and reproduction in any medium, provided the original author and source are credited.

\section{ABSTRACT}

This article scientifically analyzes the idea that the fight against ignorance and enlightenment is the humanitarian policy of Uzbekistan. The article also discusses the importance of focusing on spirituality and enlightenment in order to maintain peace and stability in modern globalization and growing ideological threats around the world.

Keywords: Ignorance, Enlightenment, Spirituality, Peace, Globalization, Idea, Ideology, Threat, Security, Stability.

\section{Introduction}

It is known from the past that the feeling of devotion to one's country in the heart of every person is the highest sign of patriotism. Basically, protecting, loving and respecting the Motherland, which is the most precious and sacred for human, requires great spiritual courage from every human. Human's ignorance of spirituality leads to ignorance, and indifference to indifference. As a result, this situation creates a basis for the destruction of a person's spirituality by losing the sense of belonging to the fate of the homeland.

This situation, in turn, requires any nation to be constantly vigilant, sensitive and vigilant against the threats to its destiny, and to think seriously about responding to them with enlightenment and spirituality. It is well known that today the world is changing rapidly, the threats to the fate and future of mankind are increasing, and fierce competition, various contradictions and contradictions are growing all over the world.

\section{Materials and Methods}

Today, the intensification of globalization is creating the conditions for the escalation of ideological threats around the world. In such an environment, it is important to focus on spirituality and enlightenment in maintaining peace and stability. In this regard, as noted by the President of Uzbekistan Shavkat Mirziyoyev: "We consider the work of spirituality and enlightenment as a work of patriotism, a work of conscience.

A person with a conscience and spirituality really loves his homeland. Conscience and spirituality mean sincere service to the people and the Motherland. This view shows the importance of spiritual education, which is widely and enthusiastically supported by all our people, especially our youth" [1].

Therefore, with the special attention paid by the head of our state Shavkat Mirziyoyev to such issues, it is becoming increasingly clear that in today's society, where new threats and dangers are emerging, it is increasingly important to strengthen a healthy environment, focus on spirituality and enlightenment. Particularly, it is very important to understand that the preservation of our great spirituality, which reflects the mentality of our nation and people, is the fate and future of our people, the task of our life and death. 


\section{Results}

The dangerous situation in the world in the era of globalization plays an important role in ensuring peace, security and stability. Globally, there is a growing ideological struggle, a clash of ideologies, and a growing desire to absorb evil ideas disguised as "beautiful" by the slogans of democracy or various religious doctrines. In particular, the existence of extremism, terrorism, bigotry, drug addiction, and threats that seek to seriously undermine world security and stability requires serious consideration. In this regard, it is becoming increasingly clear that the growing threats to the world - threats, bloody conflicts, political and economic conflicts, terrorism, the rise of radicalism - pose a serious threat to peace and stability.

At the same time, when we talk about terrorism, as a political term, it reflects the low goals of arms sales, drug trafficking, and the overthrow of the constitutional order. Terrorism is the most heinous and barbaric crime because it has always been used against religious and human norms, universal values and moral virtues. The fact that this vice, religion, nation, ethnicity and border does not choose means that the situation in this regard is extremely serious.

The abominable face of terrorism is evident in the acts of sabotage and bloodshed that are taking place in various parts of the world. Indeed, the shallowness of a healthy worldview in terms of secular and religious knowledge, the lack of understanding of the true meaning of pure religious concepts, and ignorance are driving people into the whirlpool of terrorism. In such a delicate and at the same time extremely complex environment, it is important to fight with enlightenment against the evils of terrorism, which embodies evil and destructive ideas. Today, our state and government are pursuing a well-thought-out, well-thought-out and purposeful state policy to form a healthy religious worldview in the hearts and minds of our citizens, especially young people, who are under the influence of heresies.

Nowadays, it is well known that the world community is constantly concerned about the fact that international terrorism, radicalism, bigotry and extremism do not know borders. In particular, the idea of promoting enlightenment in the fight against extremism and international terrorism has always been the main topic of President Shavkat Mirziyoyev's speeches and speeches at the international level. In his speeches, it is worth noting the initiatives of President Shavkat Mirziyoyev to address pressing issues facing the world community. Today, the initiatives and progressive ideas in this area are being promoted by President Shavkat Mirziyoyev around the world.

This current day's delicate and, at the same time, extremely complex environment, it is important to fight with enlightenment against the vices that manifest evil and destructive ideas in themselves [2]. The idea of promoting enlightenment in the fight against ignorant extremism, international terrorism and bigotry has become a major topic in the world today. Shavkat Mirziyoyev in his speech at the $72^{\text {nd }}$ session of the UN General Assembly on September 19,2017 , the head of state noted that the threat of terrorism in the world, especially in recent years, is not justified by the use of force, but by its consequences. He emphasized that the fight against terrorism was limited and that the root of international terrorism and extremism was ignorance and intolerance. Addressing the proposal to adopt a special resolution of the UN General Assembly entitled "Enlightenment and Religious Tolerance". And the President said: "The main purpose of this document is to promote the right to education, the elimination of illiteracy 
and ignorance. This resolution is aimed at promoting tolerance and mutual respect, ensuring religious freedom, protecting the rights of believers, and preventing discrimination against them ... We believe that this is the decisive condition for the successful implementation of the most important priorities of the reforms being carried out in our country, the main goal of which is to meet the needs and interests of man" [3].

Today, it is recognized that the reforms carried out by Uzbekistan in this area are setting an example for other countries in the world. In this regard, it is worth noting that on December 12, 2018, the UN General Assembly adopted a special resolution entitled "Enlightenment and Religious Tolerance". The adoption of this resolution can be considered as a practical manifestation of the initiative put forward by President Shavkat Mirziyoyev at the $72^{\text {nd }}$ session of the UN General Assembly in September 2017 in New York.

The statement was made by Helena Fraser, UN Resident Coordinator and UNDP Resident Representative in Uzbekistan. Helena Fraser: The resolution "Enlightenment and Religious Tolerance” was adopted unanimously by the UN member states. 51 countries supported the constructive proposal put forward by Uzbekistan, ie the idea of strengthening the culture of spiritual tolerance towards all religions in the world. This resolution is important because it promotes the principle of tolerance, as well as the strengthening of cultural and religious knowledge, and serves as a priority for global peace and prosperity" [4] confirmation. Ambassador Extraordinary and Plenipotentiary of the People's Republic of Bangladesh to Uzbekistan Mosud Mannon said: "The Republic of Bangladesh has always been a supporter of peace and harmony, religious tolerance. Therefore, he was one of the first to support the initiative put forward by the President of Uzbekistan. Uzbekistan is one of the most exemplary countries in the world in terms of religious tolerance. During my five years as ambassador to Uzbekistan, I have not seen any prejudice against members of other religions. On the contrary, all religions, nations and peoples live in peace, and harmony. This is a sign that the policy pursued by the President of Uzbekistan has created an atmosphere of religious tolerance in the country. In addition, this issue is due not only to the fact that it is enshrined in law, but also to the fact that the people of Uzbekistan, many of whom are Muslims, have always had respect for other religions. Friendly relations between people of different nationalities are formed, first of all, through mutual dialogue.

"The adoption of the resolution "Enlightenment and Religious Tolerance" at the UN General Assembly is the result of this positive relationship, - said Ambassador Extraordinary and Plenipotentiary of the Arab Republic of Egypt to Uzbekistan Amani Al-Itr. The common ground between our countries on this issue is that Uzbekistan and Egypt have realized that religious harmony plays an important role in the stability of society. I would like to emphasize the role of the President of the Republic of Uzbekistan Shavkat Mirziyoyev, who initiated the resolution. This is a wise initiative of Uzbekistan to find solutions to the complex problems facing the international community"[5] said, noting that the policy pursued in our country in this regard is highly recognized around the world.

\section{Discussion}

Today, changes in the global geopolitical arena, the intensification of globalization and the rapid development of modern information technologies are making a sharp turn in the world. Mankind has to live in a completely different environment, with new demands and unprecedented dangers and threats. Such rapidly evolving processes 
around the world have a serious impact on all aspects of social life, including the spiritual and educational spheres. An analysis of the tragic events taking place in different regions and countries of the world shows that the media, modern information technologies, including the Internet, social networks and electronic publications are often becoming a convenient and fast means of propagating various false, harmful ideas and ideologies in the hands of some destructive forces. Such threats lead to the erosion of national and universal values, to the root of such vices as violence, human destiny, indifference to public life, irresponsibility, indifference, carelessness, obscenity.

As a result, it causes humanity to be cut off from its historical, religious, national and spiritual roots. This situation is becoming a common trend in many countries around the world. Education and enlightenment are a key factor in human well-being. Therefore, the spiritual world of man plays an important role in preserving and enriching the resources that determine the culture of people, as well as in the struggle against evil and destructive ideas on the basis of world scientific achievements and the experience of universal development.

Now, Uzbekistan has entered a new era of national development. This can be seen in the attitude to spirituality and enlightenment, as well as radical changes in all areas. It is especially noteworthy that the reforms being carried out in country in recent years are doing great work in our country in the fight against ignorance and enlightenment. In this regard, the establishment of the Imam Bukhari International Research Center, the Center for Islamic Civilization in Uzbekistan, Imam Termezi International Research Center, the International Islamic Academy of Uzbekistan creates the basis for further development of sacred Islamic values and traditions in our country. It is noteworthy that the high attention paid to education, science, culture and enlightenment, study and appreciation of ancestral heritage is recognized not only by the people of our country and the region, but also by the world community. As much as the world civilization has benefited from the intellectual knowledge spread by the Bukharans, Fergana, Samarkand, Khorezmians, Termezis, Nasafis, this enjoyment continues today, and the invaluable heritage left by uzbek ancestors has never lost its value and significance. Even today, when the threat of borderless threats such as international terrorism, radicalism, extremism is growing around the world, enlightenment is recognized as the most effective means of combating ignorance.

Today, the reforms being carried out in Uzbekistan in the field of human rights and religious freedoms are gaining worldwide recognition. In particular, in recent years, 8 decrees on pardon of criminals have been adopted in the country, and more than 4,000 people have been released from prisons. At the same time, great efforts are being made to pardon convicts who sincerely repent of their crimes and return to a free life. A completely new practice based on the principle of humanity is being introduced in our country. As a result, 993 citizens, including 456 young men and women and 113 women, who had strayed into the path of crime and sincerely regretted their actions, were released on bail under the auspices of the Youth Union, mahallas and women's committees. As a positive continuation of this work, it is worth noting that the closure of the penal colony in Jaslyk in 2019 is a practical example of such a humane policy of our state. At the same time, for the first time, the procedure for payment of pensions and social insurance to persons deprived of their liberty has been introduced, and 709 convicts of retirement age serving their sentences in penal colonies are being paid pensions. It should be noted that this is the first step towards ensuring the right of this category of citizens to receive the pension enshrined in our Constitution. 
At the same time, in 2019, "Mehr-1" and "Mehr-2" humanitarian measures were successfully implemented, 261 people, mainly women and children, were brought back from the conflict zone in the Middle East, Afghanistan, and provided with the necessary medical and material assistance, assistance was provided. Speaking about the protection of human rights in Uzbekistan, it should be noted that over the past three years, 9,692 people, including 5,868 in 2019, were granted citizenship of Uzbekistan. The work carried out in our country in this area to form a culture of respect for human rights and freedoms in society, thereby further enhancing the international prestige of country, is recognized worldwide. This means that the work being done to ensure peace and tranquility in country requires more serious thinking about regular vigilance, vigilance and vigilance. As the head of state noted: "In order not to lag behind the sharp demands of the time and life, we must all study every day, work on ourselves, constantly improve knowledge and skills. The blood of great ancestors is flowing in veins. It is both a duty and an obligation for us to be worthy followers and successors of our great ancestors, and I think you will all agree. To work selflessly for the development of one's homeland, one's motherland: this is courage and bravery, this is love and devotion to the motherland, this is the right upbringing and practical example" [6]. Indeed, in the fight against terrorism, it is important to think deeply and act as one in the fight against terrorism with a deep understanding of the events and happenings in the world. In such an environment, it is important to pay attention to spirituality and enlightenment, first of all, in maintaining peace and stability. Changes in the global geopolitical arena, the intensification of globalization and the rapid development of modern information technologies are making a sharp turn in the world. Mankind has to live in a completely different environment, new demands and unprecedented threats and challenges. Such processes taking place in the world have a serious impact on all aspects of social life, including the spiritual and enlightenment spheres.

\section{Conclusion}

In conclusion, as noted by President Shavkat Mirziyoyev: "Of course, forgiveness and kindness are pleasing to both the people and God. Such virtues further glorify our tolerant people. Enlightenment against ignorance". This idea is crucial not only in matters related to religious education, but in all areas of our lives. It is true that if we think deeply about every issue on the basis of enlightenment, respect the people, and take into account the views of the people and solve them only on the basis of law and justice, people will be satisfied with us" [7]. Today, every citizen of country should understand that such noble deeds serve to increase the respect for holy religion of Islam by forming a healthy religious worldview and objective views on religion in the hearts and minds of all Uzbek of compatriots.

\section{Acknowledgements}

An analysis of tragic events in different regions and countries shows that the media, modern information technology, the Internet, social networks and electronic publications are in some cases becoming a convenient, fast means of propagating harmful ideas and ideologies in the hands of destructive forces. Such threats lead to the erosion of national and universal values, the root of such evils as violence, human destiny, indifference to public life, irresponsibility, indifference, carelessness, obscenity. In such a complex environment, the preservation of national and universal values, strengthening independence, ensuring socio-economic stability is one of the 
priorities of each state. Indeed, a deep understanding of the changing worldview and its essence, the mobilization of the whole society in the fight against emerging threats and dangers is an important condition for the future and development of the country. Ignorance is manifested not only in the religious form, but also in the secular, atheistic form. The time demands that the struggle against such evils on the basis of enlightenment, the issue of spirituality become a matter of conscience of all sane people in Uzbekistan. After all, enlightenment is a key factor in human well-being. Therefore, the human spiritual world plays an important role in preserving and enriching the resources that determine the culture of people, as well as in the struggle against evil, destructive ideas and enlightenment on the basis of world scientific achievements and the experience of universal development.

\section{Declarations}

\section{Source of Funding}

This research did not receive any specific grant from funding agencies in the public, commercial, or not-for-profit sectors.

\section{Competing Interests Statement}

The author declares no competing financial, professional and personal interests.

\section{Consent for publication}

Author declares that he/she consented for the publication of this research work.

\section{Ethical Approval}

Not Applicable.

\section{Availability of data and material}

Author is willing to share data and material according to the relevant needs.

\section{References}

[1] Speech by President Shavkat Mirziyoyev at the solemn ceremony dedicated to the twenty-eighth anniversary of the Independence of the Republic of Uzbekistan. http://uza.uz/oz/politics/prezident-shavkat-mirziyeevningzbekiston- respublikasi-musta-31-08-2019.

[2] Mansur Musaev. Enlightenment means the struggle against bigotry. http://postda.uz/uzc/news/spirituality/ spirituality/ 8959.

[3] President of the Republic of Uzbekistan Shavkat Mirziyoyev addressed $72^{\text {nd }}$ session of UN General Assembly. [4] A world-recognized initiative. http://www.uza.uz/oz/politics/dunye-etirof-etgan-tashabbsaus-17-12-2018.

[5] Speech by President Shavkat Mirziyoyev at the solemn ceremony dedicated to the twenty-eighth anniversary of the Independence of the Republic of Uzbekistan. http://uza.uz/oz/politics/prezident-shavkat-mirziyeevningzbekiston- respublikasi-musta-31-08-2019. 
Asian Journal of Basic Science \& Research Volume 3, Issue 3, Pages 58-64, July-September 2021

[6] Speech by President Shavkat Mirziyoyev at the solemn ceremony dedicated to the twenty-eighth anniversary of the Independence of the Republic of Uzbekistan. http://uza.uz/oz/politics/prezident-shavkat-mirziyeevningzbekiston-respublikasi-musta-31-08-2019.

[7] Turdiyev B. S. The role of national harmony in the strategy of spiritual renewal, Scientific Bulletin of Namangan State University, 2019, T. 1, №. 6, C. 229-233.

[8] Sobirovich T. B. Strategy of Renewal of National Spirituality of Uzbekistan, International Journal on Integrated Education, 2020, T. 3, №. 8, C. 122-126. 